\title{
Chromosomal Mapping of Repetitive DNA Sequences in Five Species of Astyanax (Characiformes, Characidae) Reveals Independent Location of U1 and U2 snRNA Sites and Association of U1 snRNA and 5S rDNA
}

\author{
Duilio M.Z.A. Silva Ricardo Utsunomia José C. Pansonato-Alves \\ Cláudio Oliveira Fausto Foresti \\ Departamento de Morfologia, Instituto de Biociências, Universidade Estadual Paulista, Botucatu, Brazil
}

\section{Key Words}

Fish cytogenetics · Genome evolution · Histone genes · rDNA $\cdot$ U snRNA

\begin{abstract}
Astyanax is a genus of Characidae fishes currently composed of 155 valid species. Previous cytogenetic studies revealed high chromosomal diversification among them, and several studies have been performed using traditional cytogenetic techniques to investigate karyotypes and chromosomal locations of $18 \mathrm{~S}$ and $5 \mathrm{~S}$ rDNA genes. However, only a few studies are currently available about other repetitive sequences. Here, the chromosomal location of small nuclear RNA genes, identified as $\mathrm{U} 1$ and $\mathrm{U} 2$ snRNA clusters, was established and compared to the distribution of $5 \mathrm{~S}$ rDNA and histone clusters in 5 Astyanax species (A. paranae, A. fasciatus, A. bockmanni, A. altiparanae, and $A$. jordani) using $\mathrm{FISH}$. The cytogenetic mapping of $U 1$ and $U 2$ snRNA demonstrated a conserved pattern in the number of sites per genome independent of the location in Astyanax species. The location of the U1 snRNA gene was frequently associated with $5 \mathrm{~S}$ rDNA sequences, indicating a possible interaction between the dis-
\end{abstract}

tinct repetitive DNA families. Finally, comparisons involving the location of U1 and U2 snRNA clusters in the chromosomes of Astyanax species revealed a very diverse pattern, suggesting that many rearrangements have occurred during the diversification process of this group.

(C) 2015 S. Karger AG, Basel

Astyanax Baird \& Girard is a Neotropical fish genus within the family Characidae and is currently composed of 155 valid species [Eschmeyer, 2014] that are distributed along the southern United States to central Argentina [Ornelas-Garcia et al., 2008]. The systematics of this group is still confusing and poorly understood. Several species comprise different 'species complexes', such as the A. fasciatus, A. scabripinnis, and A. altiparanae complexes, which have been established based on morphological and/or cytogenetic data [Moreira-Filho and Bertollo, 1991; Fernandes and Martins-Santos, 2004; Artoni et al., 2006; Castro et al., 2015].

In general, Astyanax species display a wide variety of diploid chromosome numbers, ranging from $2 \mathrm{n}=36$ in A. shubarti [Morelli et al., 1983] to $2 \mathrm{n}=50$ in several oth-

\section{KARGER 125}

(c) 2015 S. Karger AG, Base

$1424-8581 / 15 / 1462-0144 \$ 39.50 / 0$

E-Mail karger@karger.com

www.karger.com/cgr
Duilio M.Z.A. Silva

Departamento de Morfologia, Instituto de Biociências

Universidade Estadual Paulista, Distrito de Rubião Junior, s/n

Botucatu, SP 18618-970 (Brazil)

E-Mail duilio@ibb.unesp.br 
er species [Kavalco and Moreira-Filho, 2003; Kavalco et al., 2009a, b, 2011; Oliveira et al., 2009; Castro et al., 2015]. Moreover, the occurrence of different types of B chromosomes in their cells, the existence of distinct karyotype formulas, and the differential distribution of repetitive DNAs in closely and distantly related species all reinforce the intense and continuous dynamics of the Astyanax genome, which includes macro-chromosomal rearrangements (e.g. fissions, fusions, and inversions) and changes at the sub-chromosomal level of resolution [Fernandes and Martins-Santos, 2005; Mantovani et al., 2005; Pazza et al., 2006; Carvalho et al., 2008; Hashimoto et al., 2008; Vicari et al., 2008; Daniel et al., 2012; Santos et al., 2013; Silva et al., 2013].

Small nuclear RNA sequences are components of the spliceosome and may be characterized as 5 types, including U1, U2, U4, U5, and U6 [Valadkhan, 2005]. Cytogenetic mapping data of these sequences are restricted to $\mathrm{U} 1$ and U2 snRNA types in several organisms, including mollusks, grasshoppers, mammals, and fish [Lund and Nesbitt, 1988; Cross and Rebordinos, 2005; Cabral-deMello et al., 2012; Palacios-Gimenez et al., 2013]. Further investigation revealed the presence of $U$ snRNA clusters in distinct sex and supernumerary chromosomes of some species, which allowed for inferences to be made about their origin and evolution [Bueno et al., 2013; PalaciosGimenez et al., 2013; Utsunomia et al., 2014]. Moreover, the linkage between $\mathrm{U}$ snRNA genes and $5 \mathrm{~S}$ rDNA was also reported in different organisms which may indicate a possible evolutionary trend [Barzotti et al., 2000; Pelliccia et al., 2001; Cross and Rebordinos, 2005; Manchado et al., 2006a; Vierna et al., 2011].

In the present study, the chromosomal location of U1 and U2 snRNA clusters is established and compared with the distribution of $5 \mathrm{~S} \mathrm{rDNA}$ and histone sequences in 5 Astyanax species that currently comprise different species complexes within this genus. The main objective of the study was to develop a better understanding of the genomic organization and evolutionary dynamics of repetitive sequences in the genome of Neotropical fish. This study also sought to reveal the evolutive trends involved in the differentiation process of the species using new chromosomal markers.

\section{Material and Methods}

Sampling of Species and Mitotic Chromosomes Preparation

We collected 7 individuals of $A$. altiparanae, 19 individuals of A. bockmanni and 10 individuals of $A$. fasciatus from the Capivara River $\left(22^{\circ} 53^{\prime} 57^{\prime} \mathrm{S} / 48^{\circ} 23^{\prime} 11^{\prime} \mathrm{W}\right)$, and 38 individuals of $A$. paranae from the Cascatinha River $\left(22^{\circ} 53^{\prime} 30^{\prime \prime} \mathrm{S} / 48^{\circ} 28^{\prime} 36^{\prime \prime} \mathrm{W}\right)$. Both rivers are components of the Tietê River Basin in Botucatu, São Paulo State, Brazil. Moreover, 6 individuals of A. jordani were imported from Mexico by a local aquarium store.

The samples were collected in accordance with the Brazilian environmental protection legislation (collection permission MMA/IBAMA/SISBIO-number 3245), and the procedures for collection, maintenance, and analysis of fish specimens were performed in accordance with the international protocols on animal experimentation followed by the Universidade Estadual Paulista, UNESP. After analysis and identification, all specimens were deposited at the fish collection of the Laboratório de Biologia e Genética de Peixes (LBP), UNESP, Botucatu, SP, Brazil, under the vouchers LBP13346 (A. altiparanae), LBP13342 (A. bockmanni), LBP13344 (A. fasciatus), LBP19572 (A. paranae), and LBP19575 (A. jordani).

Mitotic chromosomes were obtained from tissue cell suspensions of the anterior kidney according to Foresti et al. [1981]. The chromosomes were classified as metacentric $(\mathrm{m})$, submetacentric (sm), subtelocentric (st), and acrocentric (a) according to Levan et al. [1964] and were arranged in descending order of size and morphology in the karyotypes.

\section{Repetitive Probes and FISH Experiments}

$5 \mathrm{~S}$ rDNA, $\mathrm{U} 2$ snRNA, and $\mathrm{H} 1$ and $\mathrm{H} 3$ histone gene probes were obtained using PCR amplification directly from the genome of $A$. paranae with previously described primers [Pendás et al., 1994; Colgan et al., 1998; Hashimoto et al., 2011; Bueno et al., 2013]. Due to the difficulty of amplifying U1 snRNA sequences in Characidae species using the primer described by Cabral-de-Mello et al. [2012], we designed a new set of primers for U1 snRNA using NGS sequencing data on A. mexicanus, which are available in GenBank, and human U1 snRNA was used as a reference. The primers were U1F ( $5^{\prime}$-GCAGTCGAGATTCCCACATT- $\left.3^{\prime}\right)$ and U1R (5'-CTTACCTGGCAGGGGAGATA- $3^{\prime}$ ). With these primers, we amplified sequences of U1 snRNA using DNA of A. paranae as a template. The reactions were performed in $1 \times$ PCR buffer, $1.5 \mathrm{mM}$ of $\mathrm{MgCl}_{2}, 200 \mathrm{mM}$ of each dNTP (dATP, dCTP, dGTP, dTTP), $0.5 \mathrm{U}$ of Taq polymerase (Invitrogen), $0.1 \mathrm{mM}$ of each primer, and $50 \mathrm{ng}$ of gDNA. The basic program used to amplify these regions consisted of denaturation at $95^{\circ} \mathrm{C}$ for $5 \mathrm{~min}$, followed by 30 cycles at $95^{\circ} \mathrm{C}$ for $30 \mathrm{~s}, 45 \mathrm{~s}$ at $54^{\circ} \mathrm{C}, 45 \mathrm{~s}$ at $72^{\circ} \mathrm{C}$, and a final extension of $5 \mathrm{~min}$ at $72^{\circ} \mathrm{C}$. The PCR experiments were conducted in a Veriti 384-well Thermal Cycler Applied Biosystems (ABI). The probes were labeled with digoxigenin-11-dUTP or biotin-16-dUTP by PCR.

Double-FISH was performed under high stringency conditions using the method described by Pinkel et al. [1986]. Slides were incubated with RNAse $(50 \mu \mathrm{g} / \mathrm{ml})$ for $1 \mathrm{~h}$ at $37^{\circ} \mathrm{C}$, and then chromosomal DNA was denatured in $70 \%$ formamide $/ 2 \times$ SSC for $5 \mathrm{~min}$ at $70^{\circ} \mathrm{C}$. For each slide, $30 \mu \mathrm{l}$ of hybridization solution containing $200 \mathrm{ng}$ of each labeled probe, $50 \%$ formamide, $2 \times$ SSC, and $10 \%$ dextran sulfate was denatured for $10 \mathrm{~min}$ at $95^{\circ} \mathrm{C}$, dropped on the slides, and hybridized overnight at $37^{\circ} \mathrm{C}$ in a $2 \times$ SSC moist chamber. Post hybridization, slides were washed in $0.2 \times \mathrm{SSC} / 15 \%$ formamide for $20 \mathrm{~min}$ at $42^{\circ} \mathrm{C}$, followed by a second wash in $0.1 \times$ SSC for $15 \mathrm{~min}$ at $60^{\circ} \mathrm{C}$ and a final wash at room temperature in $4 \times$ SSC, $0.5 \%$ Tween for $10 \mathrm{~min}$. Probe detection was performed with Avidin-FITC (Sigma) or anti-digoxigenin-rhodamine (Roche), and chromosomes were counterstained with DAPI 

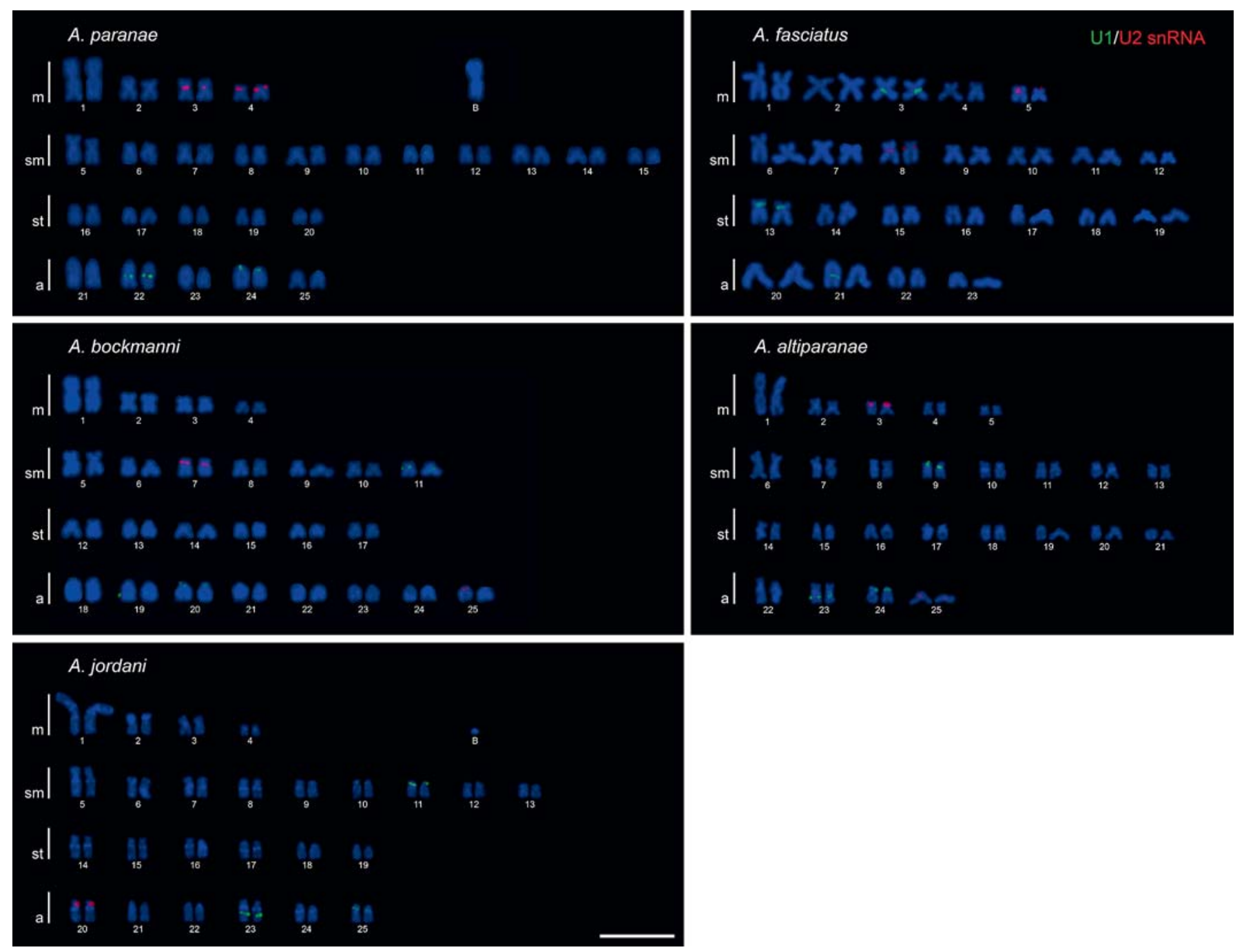

Fig. 1. Karyotypes of the Astyanax species after FISH with U1 (green) and U2 snRNA (red) probes and counterstaining with DAPI. Bar $=10 \mu \mathrm{m}$.

(4',6-diamidino-2-phenylindole, Vector Laboratories). For each species, a minimum of 20 cells was analyzed to confirm FISH results.

\section{Molecular Analysis}

U1 snRNA sequences of $A$. paranae were obtained to confirm the nucleotide composition of the probe as well as the quality of the primers described. PCR bands obtained for this gene were ligated to a TOPO TA cloning vector for transformation of One Shot TOP10 Competent Cells. Eight clones were chosen for DNA sequencing. The plasmid DNA was then isolated with the Perfectprep Plasmid Mini kit (Eppendorff), and PCR was performed with M13F (5'-GTAAAACGACGGCCAG-3') and M13R (5'-CAGGAAACAGCTATGAC- $3^{\prime}$ ) primers. The PCR products were purified using the ExoSAP-IT kit (USB Corporation) and sequenced in both directions with the Big Dye TM Terminator v 3.1 Cycle Sequencing Ready Reaction Kit (Applied Biosystems) following the manufacturer's instructions. The sequences were initially analyzed with BioEdit 5.0.9 software [Hall, 1999] and used as queries for BLAST searches [Altschul et al., 1990] against the NCBI nucleotide collection (http://www.ncbi.nlm.nih.gov/blast). Next, the U1 snRNA sequence for A. paranae was deposited in the NCBI database under the access number KP411800.

\section{Results}

Basic karyotype information revealed differences among the analyzed species. While specimens of $A$. fasciatus presented a karyotype of $2 \mathrm{n}=46$ chromosomes composed of $10 \mathrm{~m}+14 \mathrm{sm}+14 \mathrm{st}+8 \mathrm{a}$, the other 4 species showed the same $2 \mathrm{n}=50$ diploid chromosome number 

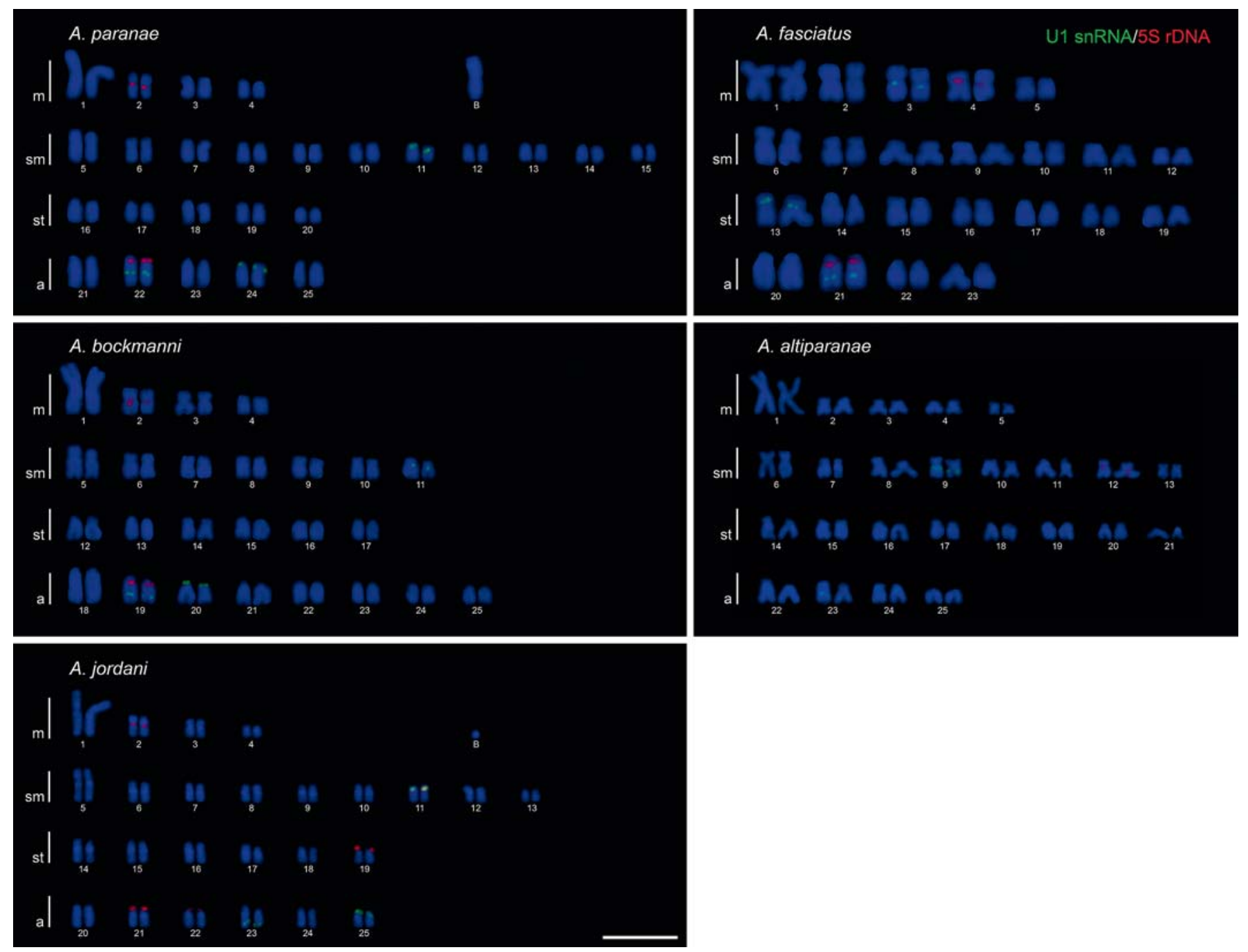

Fig. 2. Karyotypes of the Astyanax species after FISH with U1 snRNA (green) and 5S rDNA (red) probes and counterstaining with DAPI. Note the chromosomes bearing both markers. In A. jordani the sequences are co-localized on chromosomes of pair 11 , on pair 22 of A. paranae, on pair 21 of $A$. fasciatus, and on pair 19 of $A$. bockmanni. Bar $=10 \mu \mathrm{m}$.

(fig. 1). However, the following differences in the karyotype formula for these species were detected: (1) A. paranae, $8 \mathrm{~m}+22 \mathrm{sm}+10 \mathrm{st}+10 \mathrm{a}$; (2) A. bockmanni, $8 \mathrm{~m}+$ $14 \mathrm{sm}+12 \mathrm{st}+16 \mathrm{a} ;(3)$ A. altiparanae, $10 \mathrm{~m}+16 \mathrm{sm}+16 \mathrm{st}$ $+8 \mathrm{a} ;$ (4) A. jordani, $8 \mathrm{~m}+18 \mathrm{sm}+12 \mathrm{st}+12 \mathrm{a}$ (fig. 1 ). Moreover, 23 out of 38 specimens (60.5\%) of A. paranae had 1 (20 individuals) or 2 ( 3 individuals) $B$ chromosomes in $100 \%$ of the cells. Likewise, a variation from 0 to $2 \mathrm{~B}$ chromosomes was also observed in the cells of 1 out of 6 individuals of $A$. jordani.

FISH mapping with the U2 snRNA probe revealed signals in the proximal region in one chromosomal pair of A. jordani and in 2 chromosomal pairs of the other ana-

Repetitive DNA Sequences in Astyanax lyzed species (fig. 1). However, differences in the morphology of the U2-bearing chromosomes for these species were also found. In A. paranae, 2 metacentric chromosome pairs (No. 3 and 4) had U2 snRNA clusters (fig. 1), while in A. fasciatus these sequences were identified in 1 metacentric (No. 5) and 1 submetacentric pair (No. 8) (fig. 1). Additionally, U2 snRNA clusters were also identified in 1 submetacentric and 1 acrocentric chromosome pair of $A$. bockmanni, in 1 metacentric and 1 acrocentric chromosome pair of A. altiparanae, and in only 1 acrocentric pair of $A$. jordani. The U2 snRNA clusters were not associated with $5 \mathrm{~S}$ rDNA and/or $\mathrm{H} 1$ histone clusters in the chromosomes of the 5 species analyzed. 


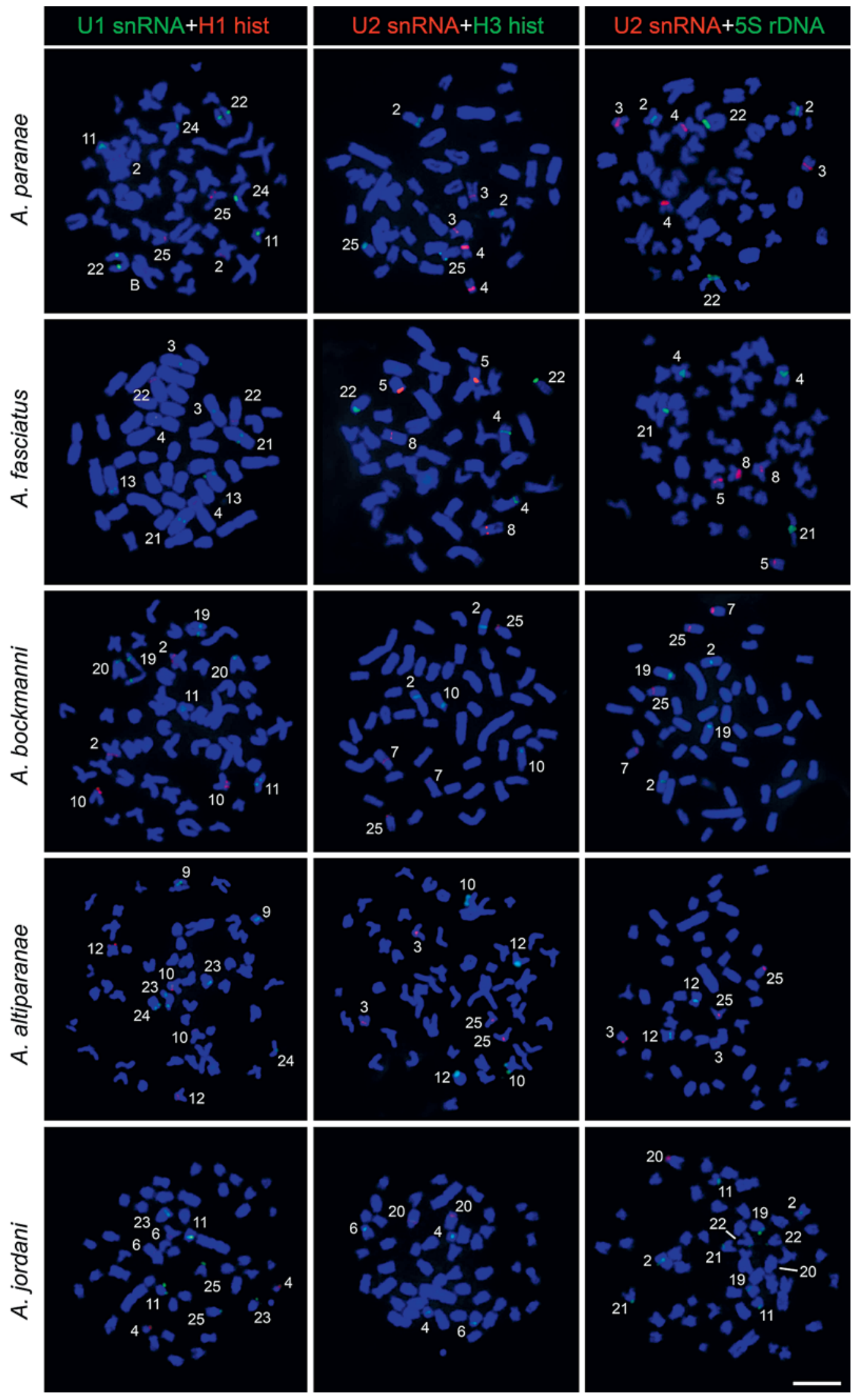

Fig. 3. Metaphases of Astyanax species after FISH with repetitive DNA probes for $\mathrm{U} 1$ and $\mathrm{U} 2$ snRNA, $\mathrm{H} 1$ and $\mathrm{H} 3$ histone genes, and $5 \mathrm{~S}$ rDNA. Numbers indicate the chromosomes that carry marked gene sequences in the metaphase plates. $\mathrm{Bar}=10 \mu \mathrm{m}$. 


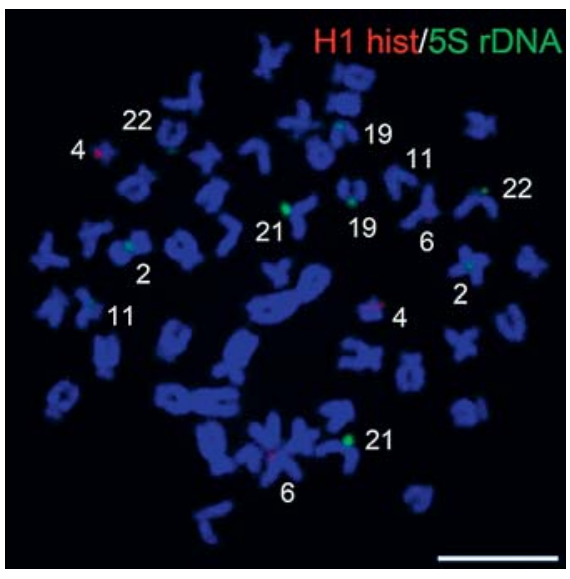

Fig. 4. Metaphase of $A$. jordani after FISH with repetitive DNA probes for $\mathrm{H} 1$ histone gene and $5 \mathrm{~S}$ rDNA and counterstaining with DAPI. Note the independent location of $5 \mathrm{~S}$ rDNA and histone gene sites. Numbers indicate the chromosomes that carry marked gene sequences. Bar $=10 \mu \mathrm{m}$.

U1 snRNA clusters were detected in 6 chromosome pairs in the 5 species analyzed (figs. 2, 3). In A. paranae, A. bockmanni, A. altiparanae, and A. jordani, the U1 snRNA clusters were identified in the proximal region of 1 submetacentric and 1 acrocentric chromosome pair and in the interstitial region of 1 acrocentric pair. These chromosomes correspond to pairs 11,22, and 24 in A. paranae; 11, 19, and 20 in A. bockmanni; 9, 23, and 24 in $A$. altiparanae; and 11, 23, and 25 in A. jordani (figs. 1-3). Furthermore, in A. fasciatus, the U1 snRNA clusters were localized to the proximal region of 1 metacentric chromosome pair (No. 3) and 1 subtelocentric (No. 13) and to the interstitial region of 1 acrocentric pair (No. 21) (figs. 1-3).

$5 \mathrm{~S}$ rDNA sequences were identified in various sites in the Astyanax species. In A. altiparanae, 1 submetacentric chromosome pair (No. 12) showed 5S rDNA sequences in the proximal region, while A. paranae, A. bockmanni, and $A$. fasciatus had these sequences in the proximal region of 1 metacentric chromosome pair (No. 2, 2, and 4, respectively) and in the distal region of one acrocentric chromosome pair (No. 22, 19, and 21, respectively). Notably, the 5S rDNA and U1 snRNA sites were syntenic for a single pair of chromosomes in A. paranae, A. bockman$n i$, and A. fasciatus (fig. 2). In A. jordani, $5 S$ rDNA clusters were observed in 5 chromosomal pairs (No. 2, 11, 19, 21 , and 22), and the 5S rDNA site is co-located with U1 snRNA in the submetacentric chromosome pair 11 (fig. 2).

The histone clusters were localized in accordance with previous studies performed by Hashimoto et al. [2010] and Silva et al. [2013, 2014], showing conserved positions in 4 chromosome pairs in all the analyzed species. Notably, $A$. jordani was the only species that did not have synteny between histone genes and minor ribosomal sites (fig. 4). Among the repetitive DNA probes for $\mathrm{U} 1$ and $\mathrm{U} 2$ snRNA, $5 \mathrm{~S}$ rDNA and histone genes were mapped, and only $\mathrm{H} 1$ histone sequences were located on the B chromosome of A. paranae, confirming previous results [Silva et al., 2014].

The nucleotide sequence obtained for U1 snRNA from A. paranae (119bp) was similar to the sequences obtained from other organisms that were available in the NCBI database. This sequence showed $94.1 \%$ similarity with the U1 snRNA gene sequence obtained from $A$. mexicanus.

\section{Discussion}

The basic karyotype information obtained from $A$. $p a-$ ranae, A. altiparanae, and $A$. fasciatus was consistent with previous reports on the diploid chromosome number and general karyotype structure. Several studies have found that $A$. fasciatus samples may have different diploid numbers in sympatric morphotypes, a phenomenon that seems to be common for this species in several Brazilian river basins [Artoni et al., 2006; Pazza et al., 2006; Pansonato-Alves et al., 2013]. In the present study, only individuals showing $2 \mathrm{n}=46$ chromosomes were collected at the sites sampled, and the karyotype found in individuals of this population is very similar to that analyzed by Hashimoto et al. [2011], although differences regarding their karyotypic formulas were observed. Notably, this phenomenon also occurred in the A. altiparanae sample analyzed here, indicating the occurrence of continuous karyotypic changes (e.g. chromosomal rearrangements) among Astyanax species and populations [Vicari et al., 2008; Pansonato-Alves et al., 2013].

The results from cytogenetic mapping of histone and $5 \mathrm{~S}$ rDNA genes were congruent with similar data obtained in these same species but sampled at other collection sites [Hashimoto et al., 2011; Pansonato-Alves et al., 2013; Silva et al., 2013], reinforcing the conserved location of these clusters in Astyanax (fig. 5). Remarkably, $A$. jordani was the only species that did not show syntenic $5 \mathrm{~S}$ rDNA and histone sites, which is probably due to the dynamics of the minor ribosomal sites in this species. In a previous study, Kavalco et al. [2007] reported the occurrence of six $5 \mathrm{~S}$ rDNA clusters in the genome of $A$. mexicanus, an ancestor of $A$. jordani [Popper, 1970]. Here, 10 clusters of $5 \mathrm{~S}$ rDNA were observed for $A$. jordani, pointing to a striking dispersion process for $5 \mathrm{~S}$ rDNA sequences during the evolutionary history of this species. 


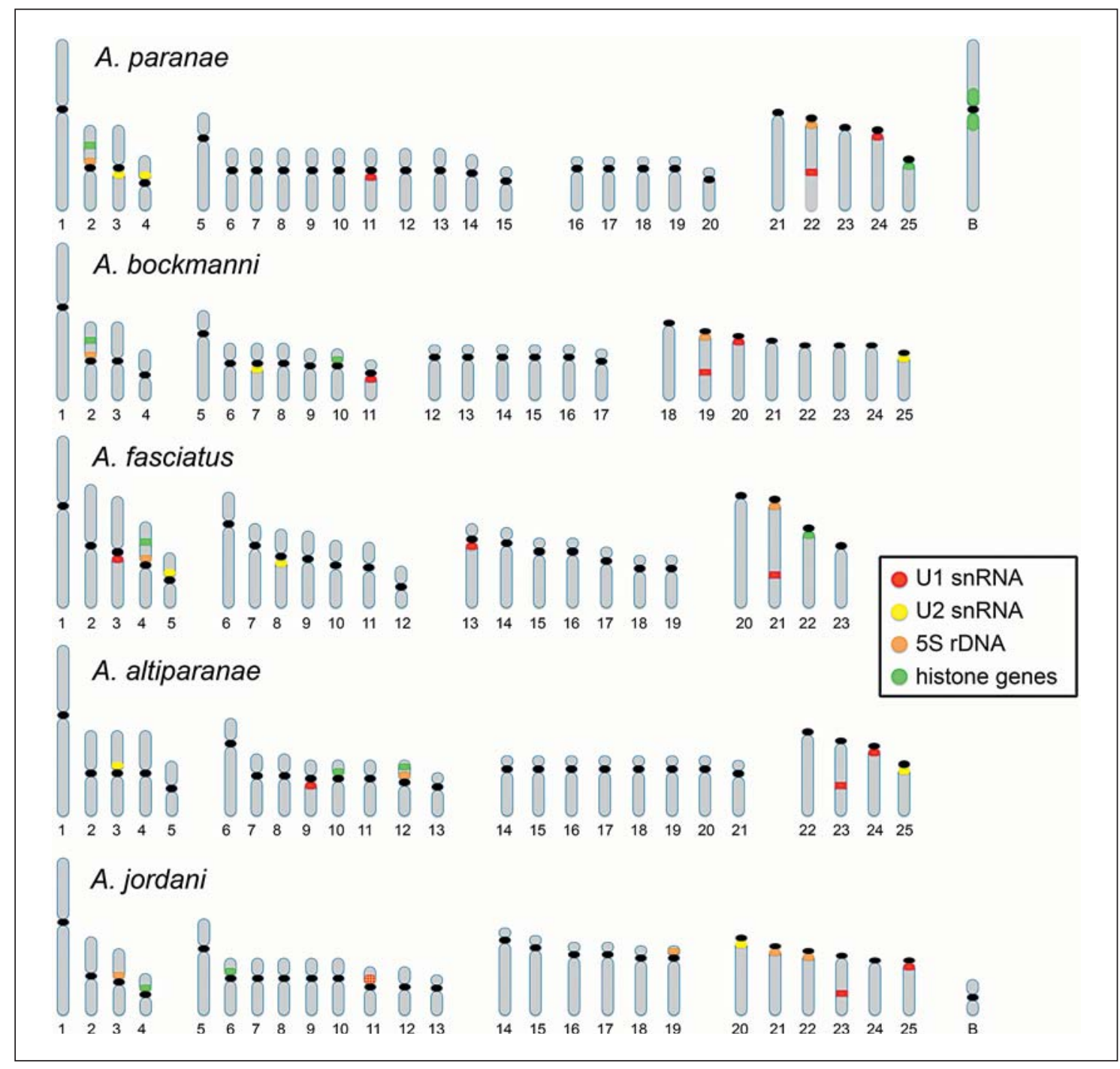

Fig. 5. Ideogram representing the karyotypes of Astyanax species with the location of the repetitive DNA sequences marked.

U1 and U2 snRNA genes showed a strong conservation in the number of sites per genome. Such a conserved feature seems to be common in different groups of fishes, with only 1 or few chromosomes per genome bearing these genes [Merlo et al., 2010; Cabral-de-Mello et al., 2012; Merlo et al., 2012 a, b; Supiwong et al., 2013; Utsunomia et al., 2014]. In several cichlid species, the U1 snRNA is clustered in a single pair, in the same manner as can be found in Gymnotus species for the U2 snRNA. However, several examples of diversification of U2 snRNA genes have already been described, including their differential dispersion and organization in closely related species [ÚbedaManzanaro et al., 2010; Utsunomia et al., 2014]. Addition- ally, the apparent absence of a linkage between these 2 small nuclear RNAs seems to be normal in fish, with few exceptions reported in the literature [Manchado et al., 2006a, b]. Moreover, the separate location of U1 and U2 snRNA clusters found in the genome of Astyanax species (fig. 1) was demonstrated in grasshoppers species as well [Bueno et al., 2013; Palacios-Gimenez et al., 2013].

Synteny between repetitive sequences can provide interesting insights into genome evolution and organization [Andrews et al., 1987; Hashimoto et al., 2012]. The proximity of histone and $5 \mathrm{~S}$ rDNA cluster sequences in one chromosome pair of several Characidae species led some authors to suggest a possible selective advantage provided by 
such association [Hashimoto et al., 2011; Silva et al., 2013, 2014]. Remarkably, other co-localization occurrences involving different repetitive sequences have been reported in Astyanax, which can be useful for understanding the organization of the genome in these species, e.g. the possible role of As51 satellite DNA in silencing major ribosomal genes [Vicari et al., 2008] or the association and potential spreading of $18 \mathrm{~S}$ rDNA genes by the Rex3 transposable element [Silva et al., 2013]. Here, we describe a novel syntenic event between U1 snRNA and $5 \mathrm{~S}$ rDNA sequences in 4 species of Astyanax. While in A. jordani these sequences are co-located in 1 submetacentric chromosome, in A. paranae, $A$. bockmanni, and A. fasciatus the U1 snRNA and 5S rDNA are clustered at different regions in the same chromosome. In A. jordani this association occurs in a submetacentric chromosome, while in the other 3 species the associated sequences are present in an acrocentric chromosome, which suggests a difference in the origin of the association process in these 4 species. The molecular association between U1 snRNA and $5 \mathrm{~S}$ rDNA sequences has already been reported in different organisms, including several razor shell species [Vierna et al., 2011] and the fish Solea senegalensis [Pelliccia et al., 2001; Manchado et al., 2006a]. However, whether it provides any selective advantage remains unclear.
U1-bearing chromosomes with similar morphology in distinct Astyanax species suggest the homology of this chromosome pair in the different species. This possibility includes those species that harbor $5 \mathrm{~S}$ rDNA sequences, but not the chromosome pair 3 of A. fasciatus, which is probably the result of a fusion with another chromosome, a hypothesis already proposed by Pansonato-Alves et al. [2013]. Conversely, the genomic location of U2 snRNA does not allow the precise identification of chromosome homology. Considering the proximal position of these sites, it can be hypothesized that multiple pericentric inversions may have occurred in these specific chromosome pairs to generate the present configuration.

Our results provided novel information about the distribution of repetitive sequences in the genome of Neotropical fish. The new set of primers provided here for the amplification of U1 snRNA works precisely in fish samples and was useful for the construction of FISH probes. The cytogenetic mapping of $\mathrm{U} 1$ and $\mathrm{U} 2$ snRNA in 5 Astyanax species revealed a conserved number of sites per genome, independent of the location, even in distantly related species. Moreover, chromosome mapping of U1 snRNA genes in Astyanax provided reliable results that may be a useful cytogenetic approach for research in other fish species.

\section{References}

Altschul SF, Gish W, Miller W, Myers EW, Lipman DJ: Basic local alignment search tool. J Mol Biol 215:403-410 (1990).

-Andrews MT, Vaughn JC, Perry BA, Bagshaw JC: Interspersion of histone and 5S RNA genes in Artemia. Gene 51:61-67 (1987).

-Artoni RF, Shibatta OA, Gross MC, Schneider CH, Almeida MC, et al: Astyanax aff. fasciatus Cuvier, 1819 (Teleostei; Characidae): evidences of a species complex in the upper Rio Tibagi basin (Paraná, Brazil). Neotrop Ichthyol 4:1997-2002 (2006).

- Barzotti R, Pelliccia F, Bucciarelli E, Rocchi A: Organization, nucleotide sequence and chromosomal mapping of a tandemly repeated unit containing the four core histone genes and a 5S rRNA gene in an isopod crustacean species. Genome 43:341-345 (2000).

Bueno D, Palacios-Gimenez OM, Cabral-de-Mello DC: Chromosomal mapping of repetitive DNAs in the grasshopper Abracris flavolineata reveal possible ancestry of the $\mathrm{B}$ chromosome and $\mathrm{H} 3$ histone spreading. PLoS One 8:e66532 (2013).

-Cabral-de-Mello DC, Valente GT, Nakajima RT, Martins C: Genomic organization and comparative chromosome mapping of the $\mathrm{U} 1$ snRNA gene in cichlid fish, with an emphasis in Oreochromis niloticus. Chromosome Res 20:279-292 (2012).

-Carvalho RA, Martins-Santos IC, Dias AL: B chromosomes: an update about their occurrence in freshwater Neotropical fishes (Teleostei). J Fish Biol 72:1907-1932 (2008).

Castro PC, Moura MO, Moreira-Filho O, Shibatta OA, Santos MH, et al: Diversity of the Astyanax scabripinnis species complex (Teleostei, Characidae) in the Atlantic forest, Brazil: species limits and evolutionary inferences. Rev Fish Biol Fisher 25:231-244 (2015).

Colgan DJ, McLauchlan A, Wilson GDF: Histone and U2 snRNA DNA sequences and arthropod molecular evolution. Aust J Zool 46:419437 (1998).

C Cross I, Rebordinos L: 5S rDNA and U2 snRNA are linked in the genome of Crassostrea angulata and Crassostrea gigas oysters: does the (CT)n(GA)n microsatellite stabilize this novel linkage of large tandem arrays. Genome 48 : 1116-1119 (2005).

Daniel SN, Hashimoto DT, Pansonato-Alves JC, Foresti F, Porto-Foresti F: Cytogenetic characterization of distinct B chromosomes in a population of the fish Astyanax bockmanni (Teleostei, Characiformes). Caryologia 65: 228-233 (2012).
Eschmeyer WN: Catalog of Fishes. California Academy of Sciences. Electronic version, accessed March 13, 2014. http://research. calacademy.org/ichthyology/catalog.

-Fernandes CA, Martins-Santos IC: Cytogenetic studies in two populations of Astyanax altiparanae (Pisces, Characiformes). Hereditas 141: 328-332 (2004).

Fernandes CA, Martins-Santos IC: Sympatric occurrence of three cytotypes and four morphological types of B chromosomes of Astyanax scabripinnis (Pisces, Characiformes) in the Ivaí River Basin, state of Paraná, Brazil. Genetica 124:301-306 (2005).

Foresti F, Toledo-Filho AS, Almeida-Toledo LF: Polymorphic nature of the nucleolus organizer regions in fishes. Cytogenet Cell Genet 31: 134-141 (1981).

Hall TA: BioEdit: a user-friendly biological sequence alignment editor and analysis program for Windows 95/98/NT. Nucleic Acids Symp Ser 41:95-98 (1999).

Hashimoto DT, Porto-Foresti F: Chromosome polymorphism and heterochromatin and nucleolar regions in two populations of the fish Astyanax bockmanni (Teleostei: Characiformes). Neotrop Ichthyol 8:861866 (2010). 
Hashimoto DT, Gonçalves VR, Bortolozzi J, Foresti F, Porto-Foresti F: First report of a B chromosome in a natural population of Astyanax altiparanae (Characiformes, Characidae). Genet Mol Biol 31:275-278 (2008).

-Hashimoto DT, Ferguson-Smith MA, Rens W, Foresti F, Porto-Foresti F: Chromosome mapping of $\mathrm{H} 1$ histone and 5S RNA gene clusters in three species of Astyanax (Teleostei: Characiformes). Cytogenet Genome Res 134:64-71 (2011).

-Hashimoto DT, Voltolin TA, Paes ADNVA, Foresti F, Bortolozzi J, et al: Cytogenetic analysis of $\mathrm{B}$ chromosomes in one population of the fish Moenkhausia sanctaefilomenae (Steindachner, 1907) (Teleostei, Characiformes). Comp Cytogen 6:141-151 (2012).

Kavalco KF, Almeida-Tolede LF: Molecular cytogenetics of blind Mexican tetra and comments on the karyotypic characteristics of genus Astyanax (Teleostei, Characidae). Zebrafish 4:103-111 (2007).

Kavalco KF, Moreira-Filho O: Cytogenetical analyses in four species of the genus Astyanax (Pisces, Characidae) from Paraíba do Sul river basin. Caryologia 56:453-461 (2003).

Kavalco KF, Pazza R, Almeida-Toledo LF: Astyanax bockmanni Vari and Castro, 2007: an ambiguous karyotype in the Astyanax genus. Genetica 136:135-139 (2009a).

Kavalco KF, Brandão KO, Pazza R, Almeida-Toledo LF: Astyanax hastatus Myers, 1928 (Teleostei, Characidae): a new species complex within the genus Astyanax? Genet Mol Biol 32:477-483 (2009b).

-Kavalco KF, Brandão KO, Garcia C, Pazza R, Almeida-Toledo LF: Comparative cytogenetics and molecular phylogeography in the group Astyanax altiparanae - Astyanax aff. bimaculatus (Teleostei, Characidae). Cytogenet Genome Res 134:108-119 (2011).

Levan A, Fredga K, Sandberg AA: Nomenclature for centromeric position of chromosomes. Hereditas 52:201-220 (1964).

Lund E, Nesbitt MN: The embryonic and adult mouse U1 snRNA genes map to different chromosomal loci. Somat Cell Mol Genet 14: 143-148 (1988).

Manchado M, Zuasti E, Cross I, Merlo A, Infante $\mathrm{C}$, et al: Molecular characterization and chromosomal mapping of the $5 \mathrm{~S}$ rRNA gene in Solea senegalensis: a new linkage to the U1, $\mathrm{U} 2$, and U5 small nuclear RNA genes. Genome 49:79-86 (2006a).

Manchado M, Rebordinos L, Infante C: U1 and U2 small nuclear RNA genetic linkage: a novel molecular tool for identification of six sole species (Soleidae, Pleuronectiformes). J Agric Food Chem 54:3765-3767 (2006b).

-Mantovani M, Abel LDDS, Moreira-Filho O: Conserved 5S and variable 45S rDNA chromosomal localization revealed by FISH in Astyanax scabripinnis (Pisces, Characidae). Genetica 123:211-216 (2005).
Merlo MA, Cross I, Chairi H, Manchado M, Rebordinos L: Analysis of three multigene families as useful tools in species characterization of two closely-related species, Dicentrarchus labrax, Dicentrarchus punctatus and their hybrids. Genes Genet Syst 85:341-349 (2010).

Merlo MA, Cross I, Palazón JL, Úbeda-Manzanaro M, Sarasquete C, Rebordinos L: Evidence for $5 \mathrm{~S}$ rDNA horizontal transfer in the toadfish Halobatrachus didactylus (Schneider, 1801) based on the analysis of three multigene families. BMC Evol Biol 12:201 (2012a).

Merlo MA, Pacchiarini T, Portela-Bens S, Cross I, Manchado M, et al: Genetic characterization of Plectorhinchus mediterraneus yields important clues about genome organization and evolution of multigene families. BMC Genet 13:33 (2012b).

Moreira-Filho O, Bertollo LC: Astyanax scabripinnis (Pisces, Characidae): a species complex. Brazil J Genet 14:331-357 (1991).

Morelli S, Bertollo LA, Foresti F, Moreira-Filho O, Toledo-Filho SA: Cytogenetic considerations on the genus Astyanax (Pisces, Characidae). I. Karyotypic variability. Caryologia 36:235-244 (1983).

Oliveira C, Foresti F, Hilsdorf AW: Genetics of Neotropical fishes: from chromosomes to populations. Fish Physiol Biochem 35:81-100 (2009).

Ornelas-García CP, Domínguez-Domínguez O, Doadrio I: Evolutionary history of the fish genus Astyanax Baird \& Girard (1854) (Actinopterygii, Characidae) in Mesoamerica reveals multiple morphological homoplasies. BMC Evol Biol 8:340 (2008).

Palacios-Gimenez OM, Castillo ER, Martí DA, Cabral-de-Mello DC: Tracking the evolution of sex chromosome systems in Melanoplinae grasshoppers through chromosomal mapping of repetitive DNA sequences. BMC Evol Biol 13:167 (2013).

Pansonato-Alves JC, Hilsdorf AWS, Utsunomia R, Silva DMZA, Oliveira C, et al: Chromosomal mapping of repetitive DNA and cytochrome $C$ oxidase I sequence analysis reveal differentiation among sympatric samples of Astyanax fasciatus (Characiformes, Characidae). Cytogenet Genome Res 141:133-42 (2013).

Pazza R, Kavalco KF, Bertollo LA: Chromosome polymorphism in Astyanax fasciatus (Teleostei, Characidae). 1. Karyotypic analysis, Ag-NORs and mapping of the $18 \mathrm{~S}$ and $5 \mathrm{~S}$ ribosomal genes in sympatric karyotypes and their possible hybrid forms. Cytogenet Genome Res 112:313-319 (2006).

Pelliccia F, Barzotti R, Bucciarelli E, Rocchi A: 5S ribosomal and U1 small nuclear RNA genes: a new linkage type in the genome of a crustacean that has three different tandemly repeated units containing $5 \mathrm{~S}$ ribosomal DNA sequences. Genome 44:331-335 (2001).

Pendás AM, Moran P, Freije JP, Garcia-Vazquez E: Chromosomal mapping and nucleotide sequence of two tandem repeats of Atlantic salmon 5S rDNA. Cytogenet Cell Genet 67: 31-36 (1994).
Pinkel D, Straume T, Gray JW: Cytogenetic analysis using quantitative, high sensitivity, fluorescence hybridization. Proc Natl Acad Sci USA 83:2934-2938 (1986).

Popper AN: Auditory capacities of the Mexican blind cave fish (Astyanax jordani) and its eyed ancestor (Astyanax mexicanus). Anim Behav 8:552-562 (1970).

-Santos LP, Castro JP, Francisco CM, Vicari MR, Almeida MC, et al: Cytogenetic analysis in the neotropical fish Astyanax goyacensis Eigenmann, 1908 (Characidae, incertae sedis): karyotype description and occurrence of $\mathrm{B}$ microchromosomes. Mol Cytogenet 6:48 (2013).

- Silva DM, Pansonato-Alves JC, Utsunomia R, Daniel SN, Hashimoto DT, et al: Chromosomal organization of repetitive DNA sequences in Astyanax bockmanni (Teleostei, Characiformes): dispersive location, association and co-localization in the genome. Genetica 141:329-336 (2013).

-Silva DM, Pansonato-Alves JC, Utsunomia R, Araya-Jaime C, Ruiz-Ruano FJ, et al: Delimiting the origin of a $\mathrm{B}$ chromosome by FISH mapping, chromosome painting and DNA sequence analysis in Astyanax paranae (Teleostei, Characiformes). PLoS One 9:e94896 (2014).

Supiwong W, Liehr T, Cioffi MB, Chaveerach A, Kosyakova N: Karyotype and cytogenetic mapping of 9 classes of repetitive DNAs in the genome of the naked catfish Mystus bocourti (Siluriformes, Bagridae). Mol Cytogenet 6:51 (2013).

- Úbeda-Manzanaro M, Merlo MA, Palazón JL, Cross I, Sarasquete C, et al: Chromosomal mapping of the major and minor ribosomal genes, (GATA)n and U2 snRNA gene by double-colour FISH in species of the Batrachoididae family. Genetica 138:787-794 (2010).

-Utsunomia R, Scacchetti PC, Pansonato-Alves JC, Oliveira C, Foresti F: Comparative chromosome mapping of U2 snRNA and 5S rRNA genes in Gymnotus Species (Gymnotiformes, Gymnotidae): evolutionary dynamics and sex chromosome linkage in G. pantanal. Cytogenet Genome Res 142:286-292 (2014).

-Valadkhan S: snRNAs as the catalysts of premRNA splicing. Curr Opin Chem Biol 9:603608 (2005)

Vicari MR, Artoni RF, Moreira-Filho O, Bertollo LA: Colocalization of repetitive DNAs and silencing of major rRNA genes. A case report of the fish Astyanax janeiroensis. Cytogenet $\mathrm{Ge}-$ nome Res 122:67-72 (2008).

-Vierna J, Jensen KT, Martínez-Lage A, GonzálezTizón AM: The linked units of $5 \mathrm{~S}$ rDNA and U1 snDNA of razor shells (Mollusca: Bivalvia: Pharidae). Heredity 107:127-142 (2011). 